A History of the Negro Troops in THE War OF the Rebellion, 1861-1865 
This page intentionally left blank 
The North's Civil War

Paul A. Cimbala, series editor 



\section{A History of the Negro Troops in the War of the Rebellion, 1861-1865}

Preceded by a Review of the Military Services of Negroes in Ancient and Modern Times

George Washington Williams with a New Introduction by John David Smith 
Copyright (C) 2012 Fordham University Press

Originally published in 1887 by Harper \& Brothers, New York

All rights reserved. No part of this publication may be reproduced, stored in a retrieval system, or transmitted in any form or by any means-electronic, mechanical, photocopy, recording, or any other-except for brief quotations in printed reviews, without the prior permission of the publisher.

Fordham University Press has no responsibility for the persistence or accuracy of URLs for external or third-party Internet websites referred to in this publication and does not guarantee that any content on such websites is, or will remain, accurate or appropriate.

Fordham University Press also publishes its books in a variety of electronic formats. Some content that appears in print may not be available in electronic books.

Library of Congress Cataloging-in-Publication Data is available from the publisher.

Printed in the United States of America

$\begin{array}{llllllll}14 & 13 & 12 & 5 & 4 & 3 & 2 & 1\end{array}$

First edition 
To

The Negro Soldiers

Who Heroically Served Their

Country

in the War of the Rebellion

This Record of Their Valor

Is Inscribed

by Their Comrade in Arms

The Author 
This page intentionally left blank 